\title{
INTRODUCTION TO THE SYMPOSIUM ON JULIAN NYARKO, “GIVING THE TREATY A PURPOSE: COMPARING THE DURABILITY OF TREATIES AND EXECUTIVE AGREEMENTS"
}

\author{
Harlan Grant Cohen*
}

With U.S. treaty practice in the spotlight for the past few years, Julian Nyarko's American Journal of International Law article, "Giving the Treaty a Purpose: Comparing the Durability of Treaties and Executive Agreements,"1 and this symposium discussing it come at an auspicious time. While some observers have continued to worry about the rapid decline in ratifications of traditional Senate-approved treaties, most recent attention has been not on how agreements start, but on how they end. The Trump Administration has announced its intention to withdraw from the Paris Climate Change Agreement, the Intermediate-range Nuclear Forces Treaty, and the agreement creating the Universal Postal Union. It has threatened to abandon the North Atlantic Treaty Organization, the World Trade Organization, and the North American Free Trade Agreement. And it has abandoned the Joint Comprehensive Plan of Action (JCPOA) and the Trans-Pacific Partnership, both once key U.S. initiatives. As the withdrawals and withdrawal threats have added up, some have focused on the different forms of these agreements under U.S. lawSenate-approved treaties under Article II of the U.S. Constitution (Article II treaties), ex ante or ex post congressional-executive agreements (CEAs), sole executive agreements made under the president's authority alone, or nonbinding political arrangements - in asking whether and how those forms might influence the processes or likelihood of U.S. withdrawal. ${ }^{2}$

Nyarko's article is not about withdrawal but about ratification. He seeks to intervene in a much older debate about the relative value of Article II treaties and CEAs as methods for binding the United States internationally. But his choice of metrics - treaty duration - is creative and new. And with its promise of finding nuggets of insight in the murky exhaust of U.S. withdrawals, Nyarko's study is tantalizing.

As Nyarko explains, the United States has multiple distinct processes for ratifying treaties. One, laid out in Article II of the U.S. Constitution, allows the president to negotiate treaties, and after receiving the advice and consent of two-thirds of the Senate, ratify them on behalf of the United States (Article II treaties). A second, developed through practice, allows the president to negotiate and, with either prior or subsequent consent of majorities of both houses of Congress, ratify the agreement (CEAs). A third relies on the president alone to bind the United States on issues within the president's constitutional authority (sole executive agreements). Assuming that the first

\footnotetext{
* Gabriel M. Wilner/UGA Foundation Professor in International Law, University of Georgia School of Law; Member, AJIL Board of Editors.

${ }^{1}$ Julian Nyarko, Giving the Treaty a Purpose: Comparing the Durability of Treaties and Executive Agreements, 113 AJIL 54 (2019).

2 See, e.g., Brandon J. Murrill, Cong. Research Serv., R45557, The President's Authority to Withdraw the United States from the North American Free Trade Agreement (NAFTA) Without Further Congressional Action (2019); Curtis A. Bradley, Exiting Congressional-Executive Agreements, 67 Duke L.J. 1615 (2018); Harold Hongju Koh, Presidential Power to Terminate International Agreements, 128 Yale L.J. Forum 432 (Nov. 12, 2018); Joel P. Trachtman, Power to Terminate U.S. Trade Agreements: The Presidential Dormant Commerce Clause Versus an Historical Gloss Half Empty, 51 INT'L Law. 445 (2018).
}

\footnotetext{
The American Society of International Law and Harlan Grant Cohen $($ 2019. This is an Open Access article, distributed under the terms of the Creative Commons Attribution licence (http://creativecommons.org/licenses/by/4.0/), which permits unrestricted re-use, distribution, and reproduction in any medium, provided the original work is properly cited.
} 
two are legally interchangeable, ${ }^{3}$ the question is whether to choose one method or the other. And the stakes of the question become even higher when weighed against the modern political reality that garnering the consent of twothirds of the Senate is simply harder than getting congressional support for a CEA. In fact, for many potential agreements, a statute authorizing future agreements may already be on the books, ready to be used. If no good reasons can be shown for choosing the Article II route, perhaps—as Oona Hathaway suggests ${ }^{4}$ — it should be abandoned altogether in favor of CEAs.

As Nyarko recounts, various scholars have sought either to explain the choices previously made between the two forms or to suggest principles for choosing in the future, focusing on the partisan make-up of the presidency and each house, the relative importance or specific subject matter of the agreement, or historical patterns, among other possible factors. The results of these studies, he suggests, have been inconclusive.

Nyarko's shrewd intervention is to look beyond hypothesized choices between Article II treaties and CEAs and instead at functional outcomes. If, observes Nyarko, Article II treaties can be shown to perform better than CEAs by some criteria, those criteria would suggest reasons to choose Article II treaties. While many treaty outcomes may be difficult to test, the duration of U.S. international agreements can be gleaned from the State Department's Treaties in Force publication. Using that data, Nyarko carefully tests whether Article II treaties or executive agreements (the data cannot distinguish between CEAs and sole executive agreements) last longer. Finding that Article II treaties last significantly longer, even when controlling for other potential explanatory factors, Nyarko cautiously suggests that duration may be a reason to choose Article II treaties over CEAs. Duration, suggests Nyarko, can be seen as a proxy for a treaty commitment's durability in the face of various pressures to withdraw or terminate. More durable agreements, in turn, may signal stronger commitments by the parties. As such, U.S. presidents might choose Article II treaties in an effort to signal their deeper commitment to particular agreements, offering greater durability to negotiating partners abroad. These novel findings raise a host of new questions about treaty design and choice in the United States.

This AJIL Unbound symposium brings together three experts on treaty processes, each uniquely well-placed to consider Nyarko's study, assumptions, and results. Each brings a different perspective on the choice between different forms of international agreement.

Edward Swaine, Professor of Law at George Washington University Law School, recently served as a reporter on treaties for the American Law Institute's Restatement (Fourth) of the Foreign Relations Law of the United States. Inspired by Nyarko's study, he asks a more basic question: What are treaties for? Swaine probes some of the assumptions underlying Nyarko's study, including who drives the choice between Article II treaties and CEAs, whether duration really signals commitment, and whether longer-lasting treaties are actually more desirable. Without discounting Nyarko's findings, Swaine suggests a variety of new, finer-grained studies that the data might inspire, concluding that "further work might well suggest decision trees of mixed methodology."

Barbara Koremenos, Professor of Political Science at the University of Michigan and an expert on treaty design, draws from her own carefully collected data to challenge Nyarko's assumptions about duration. ${ }^{6}$ As Koremenos explains, duration is not merely a function of changing preferences or exogenous shocks; it is, in fact, a conscious choice- a treaty design feature keyed to the nature of the problems the agreement seeks to solve. States may

\footnotetext{
${ }^{3}$ One might dispute this assumption, at least with regard to the agreement's domestic authority. See Edward T. Swaine, Samsons or Methuselabs? The (Potential) Virtue of Article II Treaties, 113 AJIL Unbound 173 (2019).

${ }^{4}$ Oona A. Hathaway, Treaties' End: The Past, Present, and Future of International Lawmaking in the United States, 117 YALE L.J. 1236,1241 (2008).

${ }^{5}$ Swaine, supra note 3, at 177.

${ }^{6}$ Barbara Koremenos, Duration $\neq$ Seriousness of Commitment: An Empirical and Theoretical Critique of Nyarko's Treaties vs. Executive Agreements, 113 AJIL Unbound 178 (2019).
} 
choose shorter-term treaties to allow deeper and more flexible arrangements that can evolve over time. Many of the terminated treaties in Nyarko's sample may be part of longer chains of agreements, in which old arrangements are regularly replaced by new ones. Far from signaling weak commitments, these terminated treaties may be evidence of the opposite.

Margaret Taylor, Senior Editor at Lawfare and Fellow in Governance Studies at the Brookings Institution, handled international agreements directly in her roles as Deputy Chief Counsel for the Senate Foreign Relations Committee and as Chief Counsel and Deputy Staff Director for the Democratic side of the Committee. Her response to Nyarko brings a different perspective and takes a different tack. ${ }^{7}$ Rather than respond directly, Taylor provides richly detailed accounts, based on her own experiences, of the on-the-ground Capitol Hill maneuvering behind the Convention on the Rights of People with Disabilities' (CRPD) failure to garner Senate support as an Article II treaty, the Paris Climate Agreement's ratification as an executive agreement, and Congress's enactment of a review mechanism over the nonbinding JCPOA. The stories complement Nyarko's findings, suggesting the true choice between Article II treaties and executive agreements (both with and without Congress) may reflect more complex politics of the moment, in which many different actors jockey for political credit or to deflect political blame.

Together, these three responses suggest that Nyarko's findings may be more important for the new questions they raise, the new studies they suggest, than for the answers they provide. Nyarko's study and its results have opened new lines of inquiry about the choices between different types of agreements. Swaine, for example, suggests further study of U.S. counterparts' demands - if and when other states seem sensitive to the choice of instruments the United States uses. ${ }^{8}$

Studying the choice between Article II treaties and CEAs is a product of constitutional text and doctrine, but as Nyarko's study and Koremenos's response suggest, it may be the relationship between ex ante and ex post CEAs that matters more. As Nyarko explains, ex post CEAs may be of similar duration to Article II treaties; it is the ex ante variety that tends to expire sooner. ${ }^{9}$ And Koremenos's account hints at an explanation. If termination dates are written into agreements on the assumption that they will be replaced by new, updated agreements, ex ante CEAs may be the optimal form for these arrangements. ${ }^{10}$ Using preexisting, open-ended authority, presidents can negotiate and renegotiate, without having to worry about getting new Senate or congressional approval each time. Koremenos's examples also highlight the fact that we do not know much about ex ante CEAs, the subjects they tend to cover, or the political dynamics driving their adoption. And as Swaine suggests, ${ }^{11}$ understanding those dynamics may require more focus on Congress than on the president, as the president largely responds to the ex ante statutory authority already granted, sometimes a long time ago.

Swaine's response also highlights some of our unspoken assumptions about the choice of agreement types, including that long-lasting agreements reflect deeper commitment. ${ }^{12}$ As Koremenos hints, the opposite may be true. The lack of flexibility written into the agreement may suggest that its obligations are shallower, easier to follow, or less costly to ignore. ${ }^{13}$ Hints of such a possibility crop up in Taylor's accounts as well. It is notable that of the prominent agreements she surveys, it is the CRPD, promoted as a codification of already existing U.S. laws, which

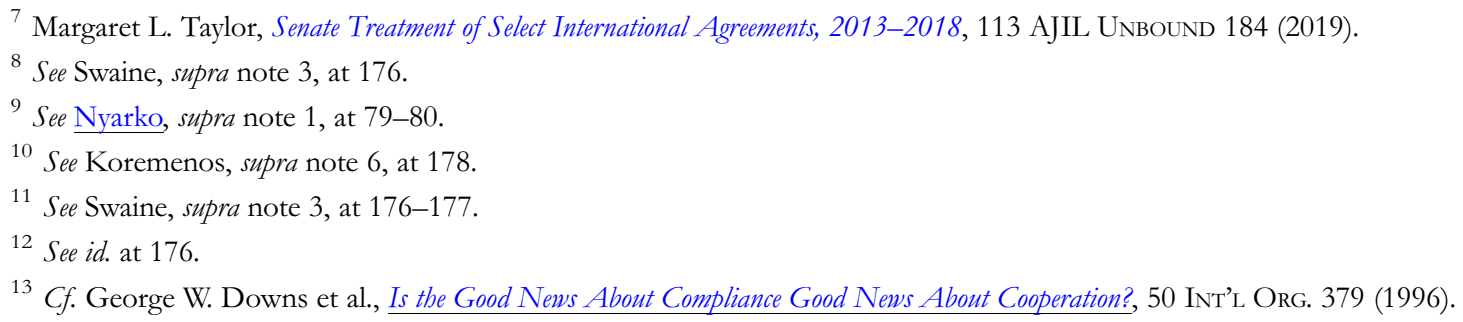


was submitted as an Article II treaty. Of the three agreements she surveys, it was also arguably the agreement the White House was least worried about ratifying or implementing. This suggests a different hypothesis about the politics of treaty form. At least in some cases, presidents may choose the Article II (or the ex post CEA) process when they want the legislative branch to share some political ownership for the agreement. (So too, the political party in charge of the Senate or House might choose to put an agreement on the agenda when it wants the other party to bear the costs of voting for or against it.) On the flip side, as Taylor suggests, congressional leaders may acquiesce to sole executive or political agreements when they would rather presidents bear an agreement's full political cost. ${ }^{14}$ Weighing in the balance, presidents may be more willing to risk the vagaries of Senate or congressional action when ratification is a lower priority, and choose ex ante authorization or negotiate on their own authority when implementation time is seemingly of the essence. Whether this hypothesis is accurate in some or many cases ${ }^{15}$ requires further study. But it is the sort of new question raised by Nyarko's new focus and data on relative treaty duration.

In the end, this AJIL Unbound symposium testifies to Nyarko's success not only in constructing a novel test of the differences between different treaty forms in the United States, but also in opening up new lines of inquiry about differences previously undernoticed or underappreciated.

${ }^{14}$ See Taylor, supra note 7, at 188.

15 As Taylor explains, some important but narrow categories of treaties (on issues such as bilateral extradition, mutual legal assistance, and maritime boundaries, among others) do continue to be submitted to and approved by the Senate, suggesting Swaine's more complex "decision trees." 